UNRAM Law Review is licensed under a Creative Commons Attribution 4.0 International License, which permits unrestricted use, distribution, and reproduction in any medium, provided the original work is properly cited. p-ISSN: 2548-9267 | e-ISSN : 2549-2365, Open Access at : http://unramlawreview.unram.ac.id/index.php/ulr

\begin{tabular}{c|c|c|c|c|}
\hline Volume & Issue & Page & October & p-ISSN: 2548-9267 \\
\hline 4 & 2 & $123-137$ & 2020 & e-ISSN : 2549-2365
\end{tabular}

\title{
Legal Protection on Franchise as Business Alternative Development
}

\author{
Erna Tri Rusmala Ratnawati \\ Jl. nDalem Mangkubumen KT III/237 Yogyakarta \\ Email: ernatr205@gmail.com \\ Hartanto \\ Jl. nDalem Mangkubumen KT III/237 Yogyakarta \\ Email: hartanto.yogya@gmail.com
}

\begin{abstract}
The growth of franchise has developed rapidly and demanded by the franchisee and franchisor, since this system containing a symbiosis mutualism where the parties are bound to each other and gain a lot of advantages. However, this systemarisesthe questions: what is the basic consideration for the franchisee before agree in the franchise agreement? What is the requirement which needs to be listed in the franchise agreement? What is the excellence of franchise as the business alternative for the franchisee? The research method of this article is legal research or also called doctrinal research which purposes to analyze the regulation on franchise business which is descriptive, this research using a conceptual/normative approach which is a research that collecting secondary data such as primary, secondary, and tertiary legal materials. Before the parties entering a franchise agreement, the franchisee must be doing some survey on the feasibility of the franchise to know and analyzing where the result will become a consideration in the decision making for the franchisee. The franchisee should be paying attention to the criteria of the franchise if it is worth buying or as partner cooperation and take into account the criminal aspect on the franchise management.
\end{abstract}

Keywords: legal protection; The franchisor; The franchisee; Franchise agreement.

\section{INTRODUCTION}

As a system, the franchise has developed for more than 30 years in Indonesia and still become the trend and in demand by the business actor. The market trend goes into food and beverage franchise where we can see a lot of culinary booths sprung up with an innovation of product which comes from abroad even in the domestic area, this matter as a concern by Putu SucitaYanthy in her Thesis ${ }^{1}$.

As for a new business actor or for those who want to expand their business, the franchise system could become an alternative and considers a win solution whether for the franchisor and the franchisee. The franchisor will provide a profit because he could delegate infestation risk while at the same time he could expand his business faster without spending more capital since the capital provided by the franchisee. Besides, the risk of

1 Putu Sucita Yanthy, https://sinta.unud.ac.id/uploads/dokumen_dir/11bf4fe6cd348445f515ea4a0a9a ba08.pdf, (accessed 7 August 2020). 
the complicated management of employees and the operation of the corporation through the franchise system may be switched to the franchisee.

Therefore, the franchisor does not need to spend all of his time and energy to manage the development of his business so that he could continuously improve and experimenting his product variation. Further, he could sell over the franchise from the previous product development.

The franchisee will gain profit in a short time since a franchisee system is usually provided with a proven system, proven product, and proven brand. The existence of a proven system providing convenience for the franchisee because all the franchisee needs to do only continuing the standard system of the franchise corporation without much thinking to make a new system that is not necessarily appropriate. As well as the proven brand, the franchisor provides a profit for the franchisee since the community as the consumer has acknowledge and familiar with the franchisor product so that the franchisee does not need to spend a big amount of money to create a brand image from the beginning. These advantages have caused people more interesting to sell or buy a franchise. Mark Schurman stated there are ten main reasons why the franchise business system have a chance to be successful much higher than a non-franchise business, which is: the success of the proved model, brand recognition, operational support, technology utilization, your potential as an owner, the franchisor could choose the most ideal franchise candidate, the support on continuity, economic scale (an affordable price), location selection and the assistance on design or construction. ${ }^{2}$

Besides providing benefits for the franchisor or the franchisee, the concept of franchise business also provides a lot of benefits and merit for the consumer. The consumer does not need to search for a good product in a standard price with excellent service and quality since the development of franchise business have reached all around the area of Indonesia whether in a city and even today have reached almost all of the regions. Other than that, the consumer also feels some value when they eating, shopping, going to the salon, even courses in the franchise productsince this is considered could raise the prestige of the consumer because the product was already famous.

However, we cannot deny that the more the franchise business sprung up the more it creates conflict. For example, the standard agreement which already provided by the franchisor while on the other situation the franchisee should just accept the agreement that is listed on the standard agreement. This condition could arise unbalancing bargaining power for the franchisee, the franchisee will be on a weak position than the franchisor.Further, it often occurred that the franchisee is not really detailed on analyzing the business prospect from the franchisor when they only tempted with the brand trend and it causes the less attention on the aspect of a proven product.

The franchise business could be held in the whole area of Indonesia. To upgrade the actors of the franchise in Indonesia so it will need to push the domestic actors mainly the small and medium entrepreneurs to grow as a reliable national franchisor and able to compete whether in domestic or abroad particularly in marketing the domestic product. Moreover,

\footnotetext{
${ }^{2}$ Mark Schnurman, https://www.franchisejournal.com/why-do-franchises-succeed-where-other-businessesfail, (accessed 6 August 2020)
} 
in the management of franchise, it could also arise the criminal problems.According to the description above, there are several problems which need todiscuss such as follow:

1. What is the main reason for the franchisee candidate before entering into a franchise agreement?

2. What is the requirement that will be contained in the agreement?

3. What is the advantage of the franchise as a business alternative for the franchisee?

4. How the legal protection work under the criminal code?

\section{METHOD}

The method of this researchis legal research or in other terms also called doctrinal research which purposes to analyze the regulation concerning a franchise that is descriptive. Descriptive research is used to explore and clarification on the social phenomenon ${ }^{3}$. The aims of this research to describe the franchise phenomenon as an alternative to developing or starting a business which demanded by society.

The approach of this research is a normative approach which is research by collecting secondary data such as primary, secondary, and tertiary legal materials. There are several approaches held by this research such as the statute approach which a legal approach and a conceptual approach. The legal approach is used to analyze deeply various regulation which governs the criteria of the franchise, while the conceptual approach was used to understanding the body of franchise agreement.

\section{ANALYSIS AND DISCUSSION}

\section{Theoretical Framework of Franchise System}

According to Amir Karamoy, ${ }^{4}$ a franchisee is a business partnership pattern that has a famous trademark together with the management system, financial and steady marketing, which then called as a franchisor, with a company or individual who could utilize and using the mark and the system owned by the franchisor, which then called as a franchisee. The franchisor should provide technical assistance, management, and marketing to the franchisee and as the reciprocal, the franchisee will pay some amount of fees to the franchisor. The partnership relationship between the parties will be established under a license/Franchise agreement.

Under business law $^{5}$ franchiseestablished when one party licenses another party to use the franchisor's trade name, trademark, commercial symbols, patents, copyrights, and other property in the distribution and selling of goods and services.

Business law defining, a franchise is a binding contract between two partners, in which the franchisor grants franchisees the right to implement their business system in exchange for the payment of fees and royalties. Simply. A franchise occurs when someone develops a business model \& then sells the rights to conduct business with this model to another entrepreneur, the franchisee. The businessman who sells the rights is the franchisor. ${ }^{6}$

\footnotetext{
${ }^{3}$ Sanapiah Faisal, (2001), Format-Format PenelitianSosial, Jakarta : Raja GrafindoPersada, p. 18

${ }^{4}$ Amir KaramoyKaramoy. (2006). Sukses Usaha Lewat Waralaba. Jakarta: Jurnalindo Aksara Grafika, p. 4

${ }^{5}$ Henry R Cheeseman, Cheeseman. (2001). Business Law, Fourth Edition. United States of Amerika: Pren tice-Hall, Inc., p. 703

${ }^{6}$ Imed Eddine \& Soheyb. (2018). “An Overview of Franchising Law: Why is it Important?”. International
} 
Article number 1 of government regulation number 42 years 2007 concerning the franchise, mentions that franchise is a special right which owned by an individual or business entity to the business system with a business characteristic to marketing goods and/or services which has proven successful and may be utilized or used by the other party according to the franchise agreement. This is following the regulation of ministry of commerce of republic Indonesia number 71 the year 2019 concerning the franchise operational.

Based on the understanding of the elements above the writer could conclude that a franchise as an exclusive right of the franchisor as the one who has the intellectual property rights (trademark, patent, trade secret, copyright, etc.) to grant permission to the franchisee to utilize the property rights as a franchise system to producing or even selling the goods and services by providing a reward for the franchisor.

\section{The parties on franchise system}

Basically, under the franchise system, two partiesinvolving each other, which are the franchisor and the franchisee. The business law ${ }^{7}$ has defined the franchisor asthe party who does the licensing in a franchise situation. Per article 1 number 3 of the trade ministry regulation number $71 / 2019$, which is the franchisor is an individual or business entity who grants a right to utilize or using a franchise that he owned to the franchisee.

On the other hand, the Business Law stated that the franchisee ${ }^{8}$ as the party who is licensed by the franchisor in a franchise situation. This statement under article 1 number 3 , the government regulation number 42 the year 2007, the franchisee is a person or business entity who receives rights from the franchisor where the rights of the franchisor will be utilized and or use by the franchisee.

The franchise agreement may contain the clauses of rights for the franchisee to point another franchisee. Therefore, the parties on the franchise system may be increased which is the continued franchisor and the continued franchisee. A continued franchisor is a person or business entity who receives rights from the franchisor to use or utilize the franchisor's rights to point out a continued franchisee. Moreover, the continued franchisee is a person or business entity who receives the right to utilize or use the rights of the continued franchisor.

The trade ministry regulation number 71 concerning the operation of franchise regulated that a franchise includes a franchisor and a franchisee. The franchisor covers:

a. A franchisor from abroad

b. A franchisor from domestic business actor

c. A continued franchisor comes from abroad or domestic

The franchisee covers:

1. A franchisee comes from abroad

2. A franchisee from domestic franchise

3. A continued franchisee comes from abroad and / or from abroad franchise.

\section{The Franchise Agreement}

The definition of franchisee ${ }^{9}$ is an agreement that the franchisor and franchisor and franchisee

\footnotetext{
Journal of Law and Public Administration, (6):41

${ }^{7}$ Henry R Cheeseman, Op.cit, p. 703

${ }^{8}$ Henry R Cheeseman, Ibid.

${ }^{9}$ Henry R Cheeseman, op.cit. p. 706.
} 
enter into that set forth the term and conditions of the franchise. A franchise agreement may be defined as follows: Generally, an agreement between a supplier of a product or service or an owner ${ }^{10}$ of a desired trademark or copyright (franchisor), and reseller (franchisee) under which the franchisee agrees to sell the franchisor product or service or to business under the franchisor's name.

The purpose of franchise registration as stated by Joseph J. Fittante is: The purpose of franchise registration and disclosure laws is to protect prospective franchisees by requiring franchisors to provide detailed disclosures before they purchase a franchise.

\section{The requirements, principles, and the elements of agreement}

The agreement should be paid attention to the principles of the freedom of contract, consensualism, pacta sun servanda, good faith or even the principle of habit. By virtue of article 1338 paragraph 1 jo article 1337 under the civil code, stated that every person has the freedom in entering an agreement to anybody, with any deal, with any form, with any name as long as the agreement does not against the law of decency and public interest. According to article 1320 under the civil code, concerning the principle of consensualism which then considers an agreement exists or occurred if there is a spoken of a deal/agree. Therefore that the agreement should be based on the good faith principle is listed under Article 1338 (3) which regulated an agreement should be based on the value of appropriateness in the society. Furthermore, Article 1339 of the civil code stated that a legal agreement will be bound as a law for those who make it (the parties)/ pacta sun servanda principle thereby an agreement also recognizes a habitual principle, which means that an agreement should follow the custom of agreement where the agreement should be accordance with the situation, whether the parties put the words explicitly or quietly on the paper of agreement, this is what is called as a naturalia under the agreement habit.

An agreementshould satisfy several requirements as follows: ${ }^{11}$ the element of essentialia as a main element which is required to be listed under an agreement, such as identity of the parties. The element of naturalia is an element that is implied or considers exist in the agreement even though the parties do not explicitly list the words in the agreement such as the principle of good faith from each party. This element also understand as a law which ruling, however, may be denied (article 1476 civil code and 1491) ${ }^{12}$, an accedentalia element as an additional element which provides by the parties such as "items that have been purchased cannot be returned", this element exist since the law does not govern it under the regulation.

\section{The rights and obligations of the franchisor and franchisee}

The franchisor obligations are:

1) The franchisor required to provide a prospectus (written proposal) of the franchise to the franchisee at the time of offering. The written prospectus of the franchise at least containing:

a. The identity of the franchisor

\footnotetext{
${ }^{10}$ Joseph J. Fittante. (2019). "Does Your Square Peg Not Fit into a Round Hole? Considerthe Discretionary Exemption”. Franchise Law Journal, 39(1):3.

${ }^{11}$ Erna Tri RusmalaRatnawati. (2020). Hukum Perdata, Seri Perikatan, Yogyakarta : Lintang Pustaka Utama, p. 63.

12 Muhammad Noor. (2015). "Penerapan Prinsip-Prinsip Hukum Perikatan Dalam Pembuatan Kontrak", Mazahib, 4(1):93.
} 
The identity identified through a photocopy of the citizen ID card of the franchisor if it is a person franchise and the photocopy of shareholders citizen ID card, commissioner, and directors if the franchise in the form of a corporation entity.

b. The business legality of the franchisor

The legality of a franchisor franchise is a technical business permit such as a personal business license, a license of tourism business, a license of education unit establishment.

c. The history of the business

The business history will describe the establishment of the business, the operation of the business as well as the development of the business

d. Organizational structure of the franchisore

e. The current two years of financial reports

f. The amount of business place

g. The list of franchisee, and

h. The rights and obligation of the franchisor and franchisee

2) The franchisor required to assist in the form of coaching, operational supervision, marketing, research, and development to the franchisee continuously, including carrying out quality control and evaluation of the business by the franchisee.

3) The franchisor and franchisee prioritize the use of domestic goods and/or services production result as long as it satisfies the quality standards which have been determined written by the franchisor.

4) The franchisor must be joining out with the small and medium entrepreneurs in the region of the franchisee or suppliers of goods and/or services as long as it satisfies the requirements of the franchisor. According to Moch. Najib ${ }^{13}$ point out that there is an indication of franchise as one of the instrument to alleviate poverty which is the existence of provision that required use of goods and/or services produced by the small entrepreneurs and agreement between the franchisor and franchisee with the small entrepreneur and agreement between the franchisor and franchisee with small entrepreneurs as the suppliers of good.

On the other hand Article 1 number 7 of trade ministry regulation Number 71/2019 stated that "an offering prospectus of the franchise is written information from the franchisor which at least explains about identity, legality, the operational history, organization structure, financial reports, the business place amount, the list of franchisee, rights, and obligations of the parties as well as the intellectual property rights of the franchisor."14

\section{The rights and obligations of franchisee}

According to the obligations of the franchisor above it could be understood that there are several rights which the franchisee get, such as:

\footnotetext{
${ }^{13}$ Moch.Najib. (2012). “Waralaba Sebagai Instrumen Pengentasan Kemiskinan Di Indonesia”, Mimbar Hu kum, 24(2): 255

${ }^{14}$ Indra. (2020). https://www.doktorhukum.com/mengenal-prospektus-penawaran-waralaba/
} 
1) The franchisee has the rights to get prospectus which will be a part of the consideration in entering the agreement

2) The franchisee has the rights in achieving assessment in the form of coaching, managerial assist, marketing, research, and franchise development from the franchisor continuously

3) The franchisee has the right to ask for using the result of domestic goods and / or services production as long as it is satisfies the written quality standard of franchisor goods and services.

4) The franchisee has the right to utilize the intellectual property rights of the franchisor as a part of the franchise product.

\section{The Main Consideration of the Franchisee Candidate before Entering the Franchise Agreement}

The agreement will be held when the franchisee formerly doing some survey on the franchise feasibility whether through social media or directly. This survey is important to be done to acknowledge and analyzing and further will be the reason for deciding to buy the franchise. In providing legal protection for the franchisee the government have set on the franchise criteria which fulfill the standard of the franchise system, which is regulated under article 3 number 42 the year 2007, stated that a franchise should satisfy several criteria such as follows:

a. Has a business characteristics

The definition of business characteristic on franchise system is when the business has product excellence or differences which is not easy to be imitated compared to other similar business which makes the consumer always looking for the characteristics, such as managerial system, the way of sale and services, or arrangement or distribution way which is a particular characteristic of the franchisor.

The characteristic of this business is very important to prove the proven brand, this is because when a business has a special characteristic it usually lasts longer and is always demanded by the consumer.

b. Proven to be profitable

The business proved to be successful if it is already results in a profit, it also can be seen from the experience of the franchisor in operating his business for about 5 years and that he already has a trick in solving the problem of his business journey and is proved with the continuity and development of the business.

In the practice often occurred that the franchisee is only tempted by a brief view of a famous market in the society without paying attention to the terms on when the business have starts to acknowledge whether the business has a proven brand and proven product. This type of analysis is very dangerous since it has the possibility that those businesses only a split second trend and will not be interested any longer because a new trend appears. c. The existence of Standard of services and goods/or services made on written offer.

The standard on services and goods/services which made on written offer is aa written standard so that a franchisee may carry out the same clear framework (standard operational procedure)

d. Easy to be taught and applied 
When the franchise is easy to be taught and apply it will also be easy for the franchisee to carry out particularly for the franchisee who has not had an experience or knowledge on the same kind of business, he could implement it well in accordance with operational guidance and continuous management which provides by the franchisor.

e. The presence of continues support

The franchisor should provide support for the franchisee continuously such as operational assistance, coaching, and promotion.

f. Registered intellectual property rights

The intellectual property rights such as the rights of brand, paten, trade secret which have been registered and proved with certificate or in process of registration in the authorized agency.

The franchise as a partnership model has the criteria which been regulated under the law, this is in purpose to protects the business actors who buy the franchise. Therefore, if it is not fulfilled the criteria as accordance with the law then a person or business entity is prohibited to use the terms of franchise or the type of franchise business operational.

\section{The body of franchise agreement}

In order to avoid conflict, a franchisee should be careful before entering into a franchise agreement and must be learning and checking thoroughly the agreement documents concerning the franchise criteria so that in the implementation of his business it will be held smoothly and get the profit as the prediction.

The franchise agreement is an innominate agreement (anonymous agreement) since this agreement does not exist or is regulated under the civil code and sprung up as a new phenomenon and demanded by society. The agreement has a flexible arrangement because the system which builds under the law of obligations as regulated under book III of civil code is an open system by the existence of the freedom of contract principle which stated under article 1338 of the civil code and the existence of anonymous agreement as listed under article 1319 of civil code.

The freedom of contract is a principle which stated that every agreement is legally binding as a law for those who made it. This article could be understood that every person is free to enter into an agreement with anybody, with any name, with any contents, with any forms as long as it is not against morality and public order. The agreement cannot be irrevocable other than the agreement of the parties or because the reasons which regulated by the law and the agreement should follow the principle of good faith.

However, even the freedom is guaranteed in making the form of agreement whether in written or oral form, authentic or unofficial but the franchise agreement has been explicitly determined must be made in the written form and using Indonesian language (Bahasa Indonesia) so that the franchise agreement is not a real agreement which only needs a word of agreed but as the formal agreement which means that for the legality of the agreement it needs a particular formality. It can be concluded that the franchise agreement does not need to be in the form of a notary deed. The parties may make the agreement unofficial by following the provision under the civil code.

Apart from the freedom of contract principle, the flexibility on making a contract also regulated under article 1319 of the civil code which stated that all of the agreement, whether 
it has a special name or not even famous with a particular name, is subject to the general regulation which listed in this chapter and the previous chapter. Article 1319 of the civil code also provides freedom for every person to make an agreement document with a name that is not covered under the civil code with requirements that have to follow the regulation concerning the agreement which mentions under book III of the civil code.

The consequences of an open system provide freedom to make the agreement however it does not without limitation but are restricted by the requirements of legal requirements of the agreement under article 1320 of the civil code, which are the deal, prowess, particular conditions, and lawful cause.

The franchise agreement has a mutual relationship. In one side the franchisee provides help for the franchisor and in other condition, the franchisee will get benefit/royalty for the franchisor so that both of the parties work together in upgrading the product market in the society through a particular way which have been determined by the franchisor. Under the positive law the provision which regulated concerning franchise agreement are listed under article 4,5 and 7 of government regulation number 42 the year 2007 with several regulations as follows:

a. The franchise held by virtue of written agreement between the franchisor and franchisee by attention to the Indonesian legal system.

b. On the written form in a foreign language, the agreement must be translated into the Indonesian language.

c. The franchise agreement must be contains at least:

1) The name and address of the parties

2) The type of intellectual property rights

3) The business operational

4) The rights and obligation of the parties

5) Assistance, facilities, operational assistance, coaching and marketing which provides by the franchisor to the franchisee.

6) The business area

7) The terms of business

8) The procedures on reward payment

9) The dispute resolution mechanism

10) The procedures on extension, termination and termination of contract.

d. The franchise agreement may contain an article of rights acceptance for the franchisee to point out another franchisee.

e. The franchisee who has the right to point another franchisee must have and implement at least one franchise business place.

In the matter if there is a termination of franchise contract unilaterally by the franchisor before the end of the contract it should be dispute through arbitration mechanism or nonlitigation because the procedures is faster and does not take too much time it also has 
private decision so that it could denying the broken relation between the franchisor and franchisee. ${ }^{15}$

\section{The advantage of franchise as an alternative business to start and developed for the fran-} chisee

According to the research by the writer, there are several advantage factors for both of the franchisor and franchisee parties, however there is also the weakness in this system, it will be described as follows:

a. The advantages of the franchise system for the franchisee

1) The franchisee will get profit in a relatively short time because of the proven system, proven product, and proven brand which already exist.

2) The proven brand proves that society is familiar and recognize the franchisor product so that the franchisee does not need to build a brand image with a cost.

3) The continuous assistance from the franchisor will help the franchisee to run the business with confident

4) Through the franchise system, the franchisee has his own business although bound by the contract with the franchisee, for this reason the franchisee will have the most effort to develop his business.

5) The proven product and proven brand will provide the franchisee with an image and famous trademark which impact in curling the promotion cost.

6) Through the franchise system the franchisee does not need to start his business from the beginning since the system is already served by the franchisor and this will saving the cost, effort, and thought.

7) The franchisee gets the right to use the intellectual property rights of the franchisor in the form of trademark, patent, copyright, trade secret concerning the process, formula, and recipes of the franchisor.

8) The franchisor will get the easy bank loan access or another money resource because of the big name of the franchisee already known by the bank.

9) The franchisee will get the information, experience from the whole network of the franchisor.

10) The business risk is small alternatively as long as it is done through the criteria and standard as the franchise system does.

11) Low-cost promotion through the joint advertising which is done by the franchisor will provide benefit for the franchisee

12) The franchisee will get convenience because all of the product stock (goods/and or services) prepared by the franchisor which means there is the guarantee of product standard

b. The weakness of franchise system for the franchisee

\footnotetext{
${ }^{15}$ Lannemey. (2015). “Akibat Hukum Pemutusan Perjanjian Franchise Secara Sepihak Oleh Franchisor Se belum Berakhirnya Kontrak”, Lex Privatum, (1-3), p 169
} 
1) The assistance and continuous coaching by the franchisor will cause the franchisee to lose his independence, this proves the big control from the franchisor.

2) There are various kinds of fee which have to be pay by the franchisee such as royalty, franchisee fees, direct expenses, marketing, and advertising fees, assignment fees under the commitment and agreement.

3) Even though the franchisee will look like he has his own business however it still under the shadows of the franchisor success.

4) The franchise system already developed by the franchisor so that the franchisee cannot be flexible in developing his business because he is bound by the franchise agreement.

5) There is product standardization which offered and the obligated to buy all of the products from the franchisor will reduce the franchisor benefit.

6) The franchisor policy is not always following with the needs of the franchisee which will cause bad relations between the franchisor and franchisee.

7) The descent of reputation from the franchisor trademark will impact the franchisee business.

c. The advantage of franchise system for the franchisor

1) The franchisor will be able to develop his business without capital spend because the capital is provided by the franchisee.

2) The franchisor may expand his business through a new market opening to the whole area because of the famous brand.

3) The franchisor will get a big benefit by only selling his business through franchisee fees, royalty fees and etc.

4) The operational cost is very low because all of the operational costs and staff salaries will be the responsibility of the franchisor.

5) The return of investment is high enough, because of the existence of several kinds of fees that the franchisor may want to, moreover if the selling running smoothly because of the franchise royalty based on the selling turnover.

6) The risk delegation of investment to the franchisee

7) The franchisor does not need to spending time and effort in developing the business so that he will have time to fix and experiment on the product variation and for the next time he could sell a new product from the previous development.

d. The weakness of franchise system for the franchisor

1) It is not easy for the franchisor to provide guidance and assistance to franchisees so that it is difficult to make changes or new business innovations.

2) The existence of too high expectations from the franchisee to get the maximum profit in the shortest possible time if it is not supported by the franchisee recipient's work ethic, it will harm the image of the franchisee 
3) If there is a change in price in terms of costs, it is difficult to explain to the franchisee.

4) The selection of improper recipients can damage the reputation and brand image of the franchisor.

\section{The Criminal Law Protection of Franchise}

The franchisor under the perspective of criminal code has the responsibility of the criminal acts of the franchisee, such as expired product, the criminal action by the employees on environmental pollution, the franchisee using the same trademark when the agreement is over. The criminal acts as mention above may have occurred will connect the corporation on control function, because the employees acting to and under the name of the franchisor (for the franchise who employed the employee from the franchisor corporation). In this matter, both the franchisor and franchisee may become victims from the criminal acts of the employees, moreover if the consumer also becomes the victim. Citing from the statement by Tobing ${ }^{16}$, the responsibility which becomes a burden of one party under the interaction with other parties should be satisfied because of the mistake from his action which causing the disadvantage of other parties. Further, according to K.Asriani, IrwanMuindan Ahmad Saleh ${ }^{17}$, this responsibility must be fulfilled not only because of the action person which under his dependents/ loss which sprung up because of the goods under his supervision.

In the implementation of the franchisee, there is apply a provision of a trade secret which is the knowledge which owns by the franchisor then be given to the franchisee as the consequences of the franchise agreement signature between the parties. The trade secret may be in the form of operational procedures, recipes, even the consumer list and produced. While the definition of a trade secret by virtue of article 1 number 1 of the act number 30 years 2000 concerning the trade secret is as the information which does not know by the general people in the field of technology and/or business, which has the economic value because can be used in the business activity and the secret is guarded by the trade secret owner.[1] In the implementation, it should be referred to the manual operation. The manual should not rule out the provision on franchise agreement; because all of those provision is important than it should fill earlier in the franchise agreement. ${ }^{18}$

The environment perspective under the act number 32 years 2009 on the protection of environment management, regulated that the franchisor or franchisee jointly and severally can become perpetrators of criminal acts of their employee's action. Article 61 to article 63. Stated that the regulation of consumers concerning the responsibility of criminal acts refers to article 61 to article 63 . Article 61 stated that: "criminal prosecution can be carried out against business actors and/ or their management" this provision shows a form of criminal responsibility that can be imposed not only on the management but also on the company. ${ }^{19}$.

\footnotetext{
${ }^{16}$ Tobing, H. C. L. (2013). TinjauanYuridis Mengenai Pembatasan Tanggung Jawab Pelaku Usaha Minuman Dalam Kemasan Terhadap Undang-Undang Nomor 8 Tahun 1999 Tentang Perlindungan Konsumen, .Jurnal Civil Law USU, 2:2).

${ }^{17}$ K. Asriani, (2018), "Perlindungan Hukum Bagi KonsumenTerhadap Produk Minuman Dan Makanan", Jurnal Petitum, 6(1), p. 35.

${ }^{18}$ K. Asriani. (2012). "Managing Intellectual Property Issues In Franchising”, World Intellectual Property Organization (WIPO), p. 33.

${ }^{19}$ I Putu Pasek (2013), "Kepastian Perlindungan Hukum Bagi Konsumen Atas Pemberlakuan Kontrak Baku", Jurnal IUS Kajian Hukumdan Keadilan, 1(4):68
} 
The franchisor or franchisee should not only notice the civil aspect on the agreement however they also need to analyze from the criminal aspect. The legal instrument of those examples above have been determined under the act on protection and operation of the environment under article 60: every person is prohibited to do dumping waste and/ or materials to environmental media without permission, and article 104 stated that: every person who did dumping waste and/ or materials to the environment without permission as mentions under article 60, will hold a criminal charge with prison for 3 years maximum and penalty for Rp. 3.000.000.000 ( three billion rupiahs) maximum.

\section{CONCLUSION}

1. The basic consideration of the franchisee candidate before entering the franchise agreement is to do a survey on the franchisor's business feasibility. The franchisee should pay attention to the business criteria which feasible to buy or become a business partner at least including the standard of the services of goods and/or services offered in written form, easy to learn` and applied for continuous support and registered intellectual property rights.

2. The franchise agreement is an innominate agreement which based on the freedom of contract principle, by virtue of this principle the parties has the rights to determine the clausal of the contract such as the name of the contract, the address of the parties, the types of intellectual property rights, the business operational, the rights and obligation of the parties, assistance, facilities, operational guidance, coaching and marketing which provided by the franchisor to the franchisee: the business area, the terms of the contract, the profit payment methods, ownership, the changing in ownership, and the rights of the heir, dispute settlement and the extension procedures, closure and termination of the contract.

3. The advantage for franchisee in running the franchise system as an alternative business to start with is that the franchisee will get the profit in a short time since implementing the business which already served with the proven system, proven product and proven brand. The proven brand means that the society already recognize and familiar with the product brand of the franchisor so that the franchisee does not need to spend a big amount of money to develop the brand image as well as the existence of guidance and assistance continuously will solve the lack of knowledge of the franchisee in implementing the business so that the franchisee will be confident to do the business.

4. Legal protection for the parties under franchisee agreement is not only regulated under the civil code however it has developed from the criminal aspect which one of the things that the parties needs to considers, through analyzing the system of law which not only describing the franchise system.

\section{Bibliography}

Books:

Cheeseman, Henry R. (2001). Business Law, Fourth Edition. United States of Amerika: Prentice-Hall, Inc.

Faisal, Sanapiah. (2001). Format-Format Penelitian Sosial. Jakarta : Raja GrafindoPersada Istanto, F Sugeng. (2007). Metode Penelitian. Jakarta: RajaGrafindo Persada. 
Karamoy, Amir. (2006). Sukses Usaha Lewat Waralaba. Jakarta: Jurnalindo Aksara Grafika.

Ratnawati, Erna. (2012). Perjanjian Tidak Bernama. Handout perkulihan. Yogyakarta: Universitas Widya Mataram

Sanapiah Faisal. (2001). Format-Format PenelitianSosial. Jakarta: Raja Grafindo Persada.

Journal Articles:

Asriani. K, Irwan Muin, Ahmad Saleh. (2018). "Perlindungan Hukum Bagi Konsumen Terhadap ProdukMinuman Dan Makanan", Jurnal Petitum, 6(1): 35

Bhakti, Gama. (2017). "RahasiaDagangDalam Usaha Franchise Di BidangKuliner", LiterasiHukum, (4-1): 14

Chairunisa, Agri. (2020). "Perbandingan Franchise Offering Circular Menurut Pranata Hukum Waralaba Di Indonesia Dan Australia", Veritaset Justitia, 6(1):80

Eddine, Imed\&Soheyb. (2018). "An Overview of Franchising Law: Why is it Important?", International Journal of Law and Public Administration, (6):41

Fittante ,Joseph J (2019). "Does Your Square Peg Not Fit into a Round Hole? Considerthe Discretionary Exemption”. Franchise Law Journal, 39(1):3

Lannemey. (2015). "Akibat Hukum Pemutusan Perjanjian Franchise Secara Sepihak Oleh Franchisor Sebelum Berakhirnya Kontrak", Lex Privatum, (1-3): 169

Najib.Moch. (2012), "Waralaba Sebagai Instrumen Pengentasan Kemiskinan Di Indonesia", Mimbar Hukum, 24(2): 255

Noor. Muhammad. (2015), "Penerapan Prinsip-Prinsip Hukum Perikatan Dalam Pembuatan Kontrak", Mazahib, 4(1):93

Pasek, I Putu (2013), "Kepastian Perlindungan Hukum Bagi Konsumen Atas Pemberlakuan Kontrak Baku", Jurnal IUS Kajian Hukum dan Keadilan, 1(4): 68

(2012). "Managing Intellectual Property Issues In Franchising", Worl Intellectual Property Organization (WIPO), 33

Regulation:

KUHPerdata $(B W)$

Undang-Undang Nomor 28 Tahun 2014 tentang Hak Cipta

Undang-Undang Nomor 32 tahun 2009 tentang Perlindungan dan Pengelolaan Lingkungan Hidup.

Undang-Undang Nomor 30 Tahun 2000 tentang Rahasia Dagang

Peraturan Pemerintah Nomor 42 Tahun 2007 Tentang Waralaba

Peraturan Menteri Perdagangan Republik Indonesia Nomor:31/M-DAG/PER/8/2008 Tentang Penyelenggaraan Waralaba

Peraturan Menteri Perdagangan Republik Indonesia Nomor 71 Tahun 2019 Tentang Penyelenggaraan Waralaba.

Internet:

Indra.(2020).https://www.doktorhukum.com/mengenal-prospektus-penawaran-waralaba/, (accessed 6 Agustus 2020) 
Mark Schnurman,https://www.franchisejournal.com/why-do-franchises-succeed-where-otherbusinesses-fail, (accessed 6 Agustus 2020)

Putu Sucita Yanthy, (Disertasi) https://sinta.unud.ac.id/uploads/dokumen dir/11bf4fe6cd3484 45f515ea4a0a9aba08.pdf, (accessed 7 Agustus 2020 